failures and some results in testing existing indexing systems. Although he comments briefly on the results of the whole investigation and discusses briefly basic problems in retrieving information, from the point of view of the general reader or scientist this report adds little to tho interim report already noted in Nature $(189,359$; 1961).

\section{Nonconventional Technical Information Systems}

THE third of a series of reports on Nonconventional Technical Information Systems in Current Use, issued by the National Science Foundation, deseribes 87 such systems from 73 different organizations, six of whom reported two systems each, one three, and one seven (No. 3. NSF-62-34. Pp. $x x+209$. Washington, D.C.: National Science Foundation, 1962). About half the organizations are new to the series, and three systems outside the United States are included. As in previous reports, the information is arranged under three main headings: systems which store references; systems which store data; and systems which produce general search aids. Comments on the compilation are invited and also information on other systems for possible inclusion in future reports.

\section{The U.S. Office of Aerospace Research}

Bulletin No. 15, September 1962, NSF 62-17, Scientific Information Activities of Federal Agencies, issued by the National Science Foundation, the first of four bulletins to deal with the U.S. Air Force, describes the activities of the Office of Aerospace Research, which is responsible for most of the basic research carried out or sponsored by the Air Force. Besides describing the various organizational units, the Bulletin includes information on the various fields of research, the progress being made and the types of publication issued.

\section{A New High-sensitivity Colorimeter}

A NEW Unicam SP. 1300 colorimeter, made by Unicam Instruments, Ltd., Cambridge, has a technical spocification which incorporates many of the latest advances in colorimetry. Outstanding features include: (a) autofil cell-automatic system of filling and emptying cells, saving time and avoiding spillage (minimum volume of 10-mm glass sample well-2 ml.); (b) single lever control for three stages of analysis; $(c)$ instant selection of filters by rotation of filtor disk. Initially introduced with a series of sixteen clinical methods, the $S P .1300$ is equally suitable for a very wide range of colorimetric analyses. The instrument will be supplied complete with a multiring binder containing operating instructions and methods of analysis for sixteon separate clinical determinations (other 'method sheets' will be made availablo to the users within a short space of time). Tho styling of this new Unicam instrument will fit well into the modern laboratory. It is compact, sturdy and easily transportable.

\section{Ground Reflexion Interference Patterns}

The purpose of the National Bureau of Standards Monograph 38, issued on April 2, is to give the results of a detailed computation of ground reflexion interference patterns in the lower ionosphore at VHF over a spherical oarth (Radiation Patterns in the Lower Ionosphere and Fresnel Zones for Elevated Antennas Over a Spherical Earth. Pp. iii + 128. Washington, D.C.: Govornmont Printing Office, 1962. 70 cents). The computations cover parallax, tropospheric rofraction and dofocusing, spherical divergence, and near horizon diffraction. From the patterns, three antenna-siting parameters--the antenna height and olovation angle for placing the maximum of the first lobe at the path midpoint (called the lobo alignment height); the distances from the antonna to the edges and tho quarter-wave contour of the first Fresnel zone on the Earth's surface; and information for the determination of effects of obstacles located in the first Frosnel zono-have been computed. The antenna hoight- gain function calculated from the results has boon proviously published (Institute of Radio Engineers Trans. actions on Communications Systems CS-8, 14-19; March 1960). The function shows that the optimum height is lower than the lobe alignment height and that a broad range of lowor heights is essentially oquivalent in gain to the lobe alignment height. The results prosented in the monograph refer to an ionospheric scattering layor hoight of $85 \mathrm{~km}$ at frequencies of $30-55 \mathrm{Mc} / \mathrm{s}$, which have boen found to be the most usoful values. They correspond to computed path lengths of $1,000-2,400 \mathrm{~km}$. Two refractivitios representing 'standard rofraction' and temperate. over-water or tropical 'wet' refraction were used. The monograph contains some hundrod graphs, and in the appendixes lobe alignment antenna heights and other data, together with symbols and equations, are tabulated and a mathematical discussion of the lobe shift is given.

\section{Farm Buildings Research}

A BIBLIOGRAPHY, Farm Buildings Research, was issued by the Agricultural Research Council in 1958, covering publications of the previous three years. The first supplement to Part I of the general bibliography, covering publications of the three years ending in 1961, and also items omitted from the previous issue, has recently boon published (Pp. 69. Agricultural Research Council, 1962. 4s.). This deals with buildings for pigs and provides a brief annotation for each reforenco quoted. An author index to the references is included.

\section{Animal Disease in Israel}

The reports of the Vetorinary Department in Isreel for 1959 and for 1960 were published in Hebrew, but a report in English has now been issued for both years. Israel is inevitably an important area so far as tho fiold of animal diseases is concerned. With its very central situation on certain travel routes botweon East and Wost and with some extensive terrain in its vicinity with, perhaps, less well-developed veterinary sorvices, opportunitios can occur of certain infectivo disoases to pass into regions that might bo danger areas to other countrios. With its strong scientific outlook Israel is a source of strength, in that new introductions of spreading disease are likely to be detected at an early stage, with quick introduction of control measures. In recent years, African horsesicknoss, as an escape from Africa, has been the cause of great. lossos as far afield as India-Israel being a steppingstone in its progress. Bluotongue of sheop has similarly escaped from Africa and spread quite disastrously in recent decades. Similarly, African swine fover, caused by a virus different from that of the well-known swine fever, has invaded European countries with sorious results, though, fortunately, active control moasures have limited the risk to all but a fow countries. Details are given of the activitios in Israel for dealing with thirty-five scheduled diseases of mammals and with scheduled poultry diseasos-the diseases given special attention in all countries because of particular liability to spread. The Government voterinary field service is handicapped by a sorious lack of manpower. Rabies occurred from 1948 onwards in animals, including, as woll as domestic animals, jackals, foxes, hyenas, wolves and a mongoose. There were reports of 69,995 persons being bitten, and 11,588 were given anti-rabies treatmont.

\section{Natural History of the British Solomon Islands}

THE fourth volume of the sciontific results of the joint Danish (1951) and British Museum (Natural History) (1953) expoditions to Rennell Island has been published under the general editorship of Torbon Wolff (The Natural History of Rennell Island, British Solomon Islands. 4: (Invortebrates, Pars; and addition to Vertebrates). Pp. $120+18$ plates. Copenhagen: Danish Scionce Press, Ltd. Published by the University, Copenhagen; and the 